\title{
Fluids Expelled Tectonically and Their Significance in Hydrocarbon Migration
}

\author{
Katarzyna Jarmołowicz-Szulc \\ Polish Geological Institute - National Research Institute, Warsaw, Poland
}

\begin{abstract}
Oliver (1986) postulated that when continental margins in zones of convergence are buried beneath thrust sheets, fluids expelled from the margin sediments go to the foreland basin and the continental interior. It might be stated that these fluids play key role in different phenomena. That concerns faulting, migration of hydrocarbons, and mineral transportation etc. The hypothesis has been presented based on the North American case, relating both oil and gas fields and their occurrences as well as e.g., lead-zinc deposits to the tectonic belts there (as the Appalachians). Furthermore the presentation concerns the Carpathian Mountains chain in Europe, a fragment of the orogenic belt that cuts a large part of the continent, and oil and gas fields there, present in the Carpathians and the Carpathian Foreland. Hydrocarbons are very common and widespread in sedimentary rocks in the different Carpathian units and at different scale (macro-and microscopic) and point to mobility and circulation of fluids.
\end{abstract}

Keywords: fluids, tectonics, hydrocarbons, migration

\section{INTRODUCTION}

Fluids expelled from the margin sediments when continental margins in zones of convergence are buried beneath thrust sheets, go to the foreland basin and the continental interior(Oliver, 1986). These fluids are significant for different phenomena, as e.g., faulting, migration of hydrocarbons, and mineral transportation. The hypothesis has been presented based on the very good North American example, relating both the presence of oil and gas, and occurrences of the fields to the tectonic belts there. In Europe, where the Carpathian Mountains chain is a fragment of the orogenic belt that cuts a large part of the continent, oil and gas fields are present in the Carpathians and the Carpathian Foreland, as well as hydrocarbons are accessible at the microscopic scale - in fluid inclusions in minerals in the rocks. The evidence of hydrocarbons in the sedimentary rocks at micro-scale has been already mentioned in general by Roedder (1984), and it is proved by recent publications concerning brine and hydrocarbon inclusions in the distinct zones at the Polish-Ukrainian boundary (Jankowski, Jarmołowicz-Szulc, 2009; Jarmołowicz-Szulc, 2009 Jarmołowicz-Szulc et al., 2012; JarmołowiczSzulc, 2016). The aim of the present communication is to acknowledge the problematic of correlations between tectonic engagement and fluid origin and character, deposits as well.

\section{Hypothesis ANd The NorTh AMERICAN CASE}

As it has been postulated by Oliver (1986), when continental margins in zones of convergence are buried beneath thrust sheets, fluids expelled from the margin sediments go to the foreland basin and the continental interior. These fluids play key role in different phenomena, as e.g., faulting, migration of hydrocarbons, and mineral transportation.

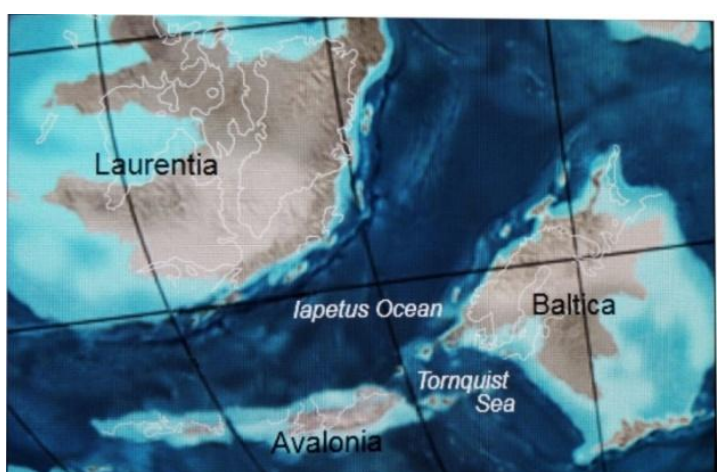

Fig1. Presence of the Iapetus Ocean. From: Google Earth. 
Let us observe the situation of the late Precambrian and early Paleozoic times when at the Iapetus Ocean existed between the Laurentia and Baltica continents, roughly at the position of the present Atlantic Ocean (Fig.1).

The formation of the Appalachians in the eastern United States related in detail in many papers (e.g. Cook et al., 1983, Oliver, 1986, Hopper et al., 2016) is a result of the continents movement, ocean closure and the collision between North America and Africa. The tectonic history of the Appalachian area may be shown in the simplified form of three stages, as it is presented in the figure (Fig. 2). Those stages correspond to the following ones: - the period of passive continental margin with margin sediments (stage 1), - the period of the thrust sheet movement and overriding the margin sediments, the subsidence as well (stage2), - the period of continents' collision and the advance of the thrust sheet (stage 3). When the margin and other later formed sediments are overridden by the thrust sheet, there occur different processes in the sediments, as sediments deformation, burial etc. When thesediments are buried, the fluidswhich fill in the pores and the minerals are expelled. Different processes may be involved due to the depth and temperature. The expelled fluids may be hot or cold, released at shallow or

Stage 1

MARGIN SEDIMENTS

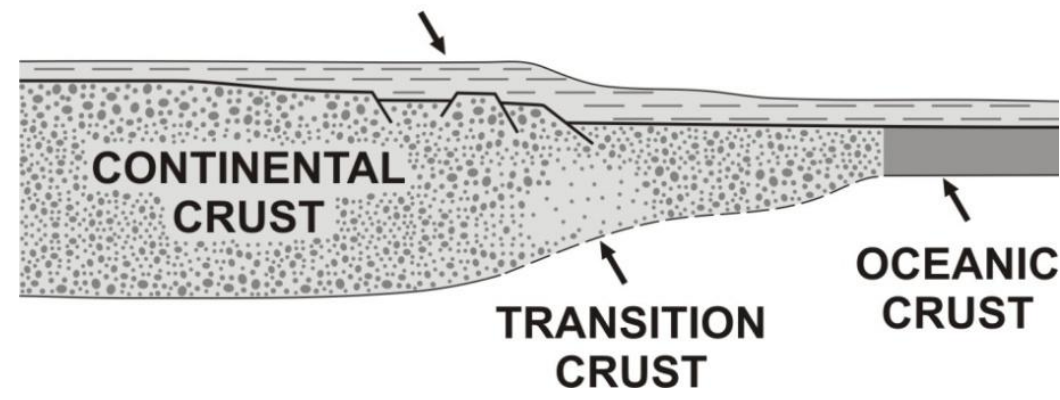

Stage 2

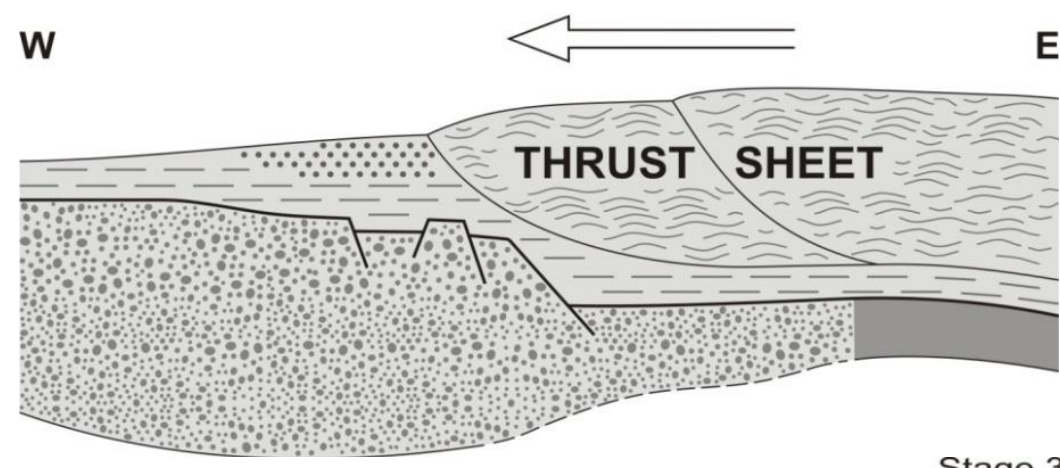

E

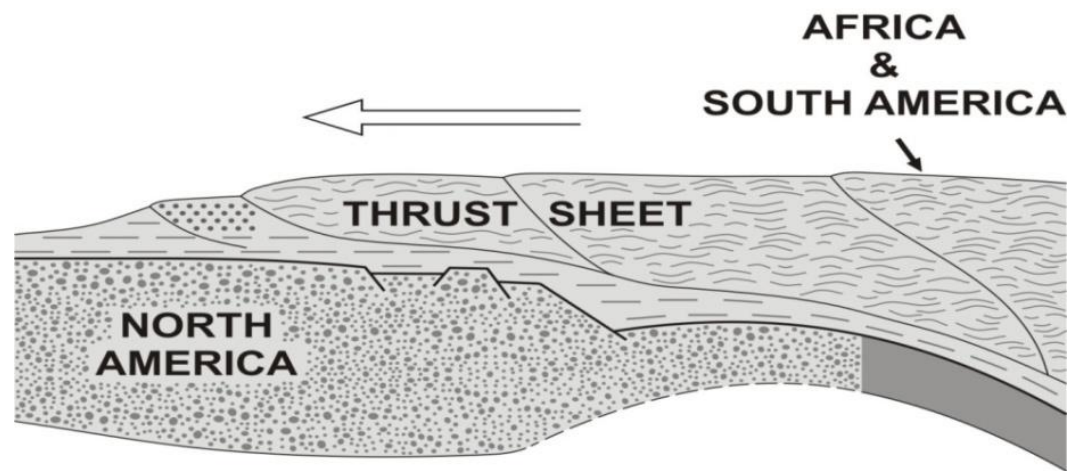

Fig2. Tectonic history of the orogen (Appalachians) - simplified. After Oliver (1986), modified. Out of scale. 
great depths. Of course there occur different processes in the meantime. However, the fact is that e.g., the compaction and diagenesis may reduce the primary huge sediment volume, a fluid production reaching up to one-third or one-half of the sediment volume. These masses of fluids may go back to the ocean and/or may be forced by the thrust sheet to the adjacent part of the continents. That is the point for further considerations. As it is seen in the figure, (Fig. 3) the process of fluid expelling from deep sources can be presented in a simple way.

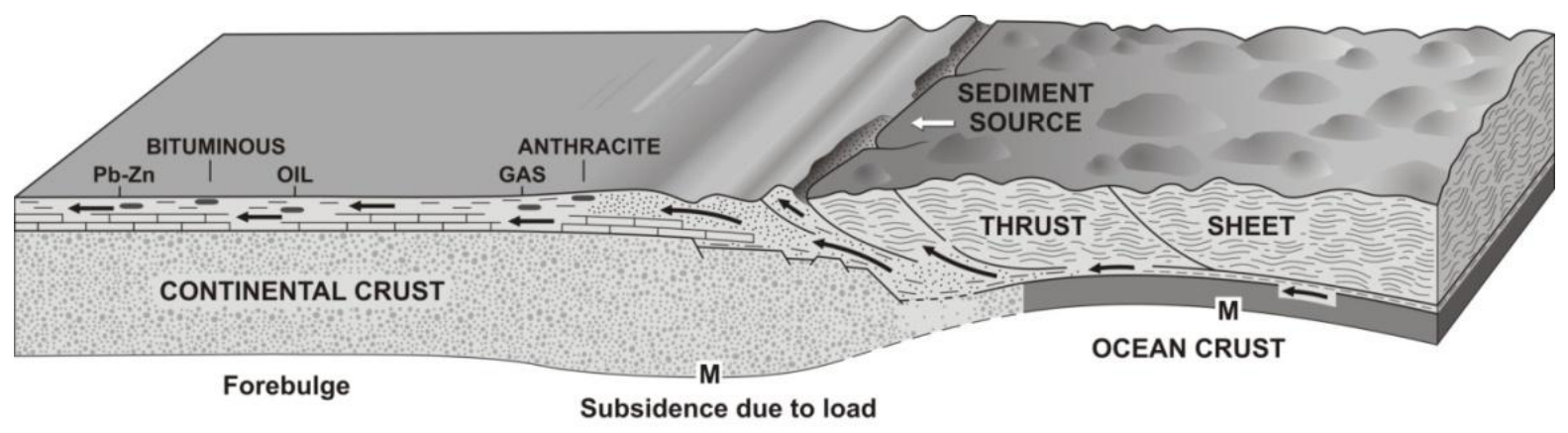

$\longleftarrow$ TECTONIC BRINES

Fig3. Possible paths for fluids expelled tectonically with a reference to potential deposits. A general simplified model of orogen development. After Oliver (1986), modified, out of scale.

The ways from fluids (mostly brines carrying heat, minerals and ingredients for petroleum) are different. Fluids can go directly upward producing veins and dikes in the metamorphic interior of mountain belts. They can be manifested as hot springs emerged from the orogeny. They can migrate in zones of decollement facilitating thrusting. They may mix with meteoric waters and/or mobilize material on their way. Finally, the fluids may reach the tectonic belts' forelandsand may be responsible for the formation of different deposits from anthracite through gas and oil fields to leadzinc accumulations (Fig. 3).

This conception is very simplified and it does not take many other complicated processes as local fluid-rock interaction, magmatic activities etc.into account. However, the pattern of oil and gas fields occurrences in North America is a good example for the conception of the tectonically expelled fluids. The oil and gas fields in the central -east United States may be referred to the Appalachian and to the Quachita Belts, the lead - zinc occurrences as well (Leach et al., 1984). Recently the scientists reconstruct formation of southern Appalachians (Hopper et al., 2016).

The orogen formation in Alberta, Canada, although later in time, has the similar pattern as that presented in figure 2 (with some magmatic activities that was not taken into account in the model there), consequences of oil and gas fields correlated with the tectonic cordilliera as well (Mosier, Waples, 1985).

\section{THE CARPATHIAN PROBLEMATICS}

In Europe, the Carpathian Mountains chain is a fragment of the orogenic belt that cuts a large part of the continent (Fig. 4). As it is seen in the figure (Fig. 4), the vergence of the units in the Carpathians in their northern part (Poland, Ukraine) is toward NE, i.e. in the direction of the Carpathian Foredeep. The so called PieninyKlippen Belt being the boundary zone between the Inner and Outer Carpathians(blue in the figure) can be concerned as the region of subduction (Roca et al., 1995). The Carpathians within Slovak, Poland and Ukraine boundaries and their foreland have been reported as the North Carpathian basin ( Pawlewicz, 2006). Oil and gas fields are present in the Outer Carpathians and the Carpathian Foreland, as well as hydrocarbons are accessible at the microscopic scale - in fluid inclusions in minerals in the rocks. Such an evidence of brine and hydrocarbon inclusions has been mentioned in general by Roedder (1984), and in the areaunder discussion it is proved by recent publications concerning brine and hydrocarbon inclusions in the distinct zones at the PolishUkrainian-Slovak boundary (Jarmołowicz-Szulc, Dudok, 2000; Jarmołowicz-Szulc, Dudok, 2005; Jankowski, Jarmołowicz-Szulc, 2011; Jarmołowicz-Szulc et al., 2012; Jarmołowicz-Szulc, Jankowski, 2013; Jarmołowicz-Szulc, 2016).The key role in the hydrocarbon 


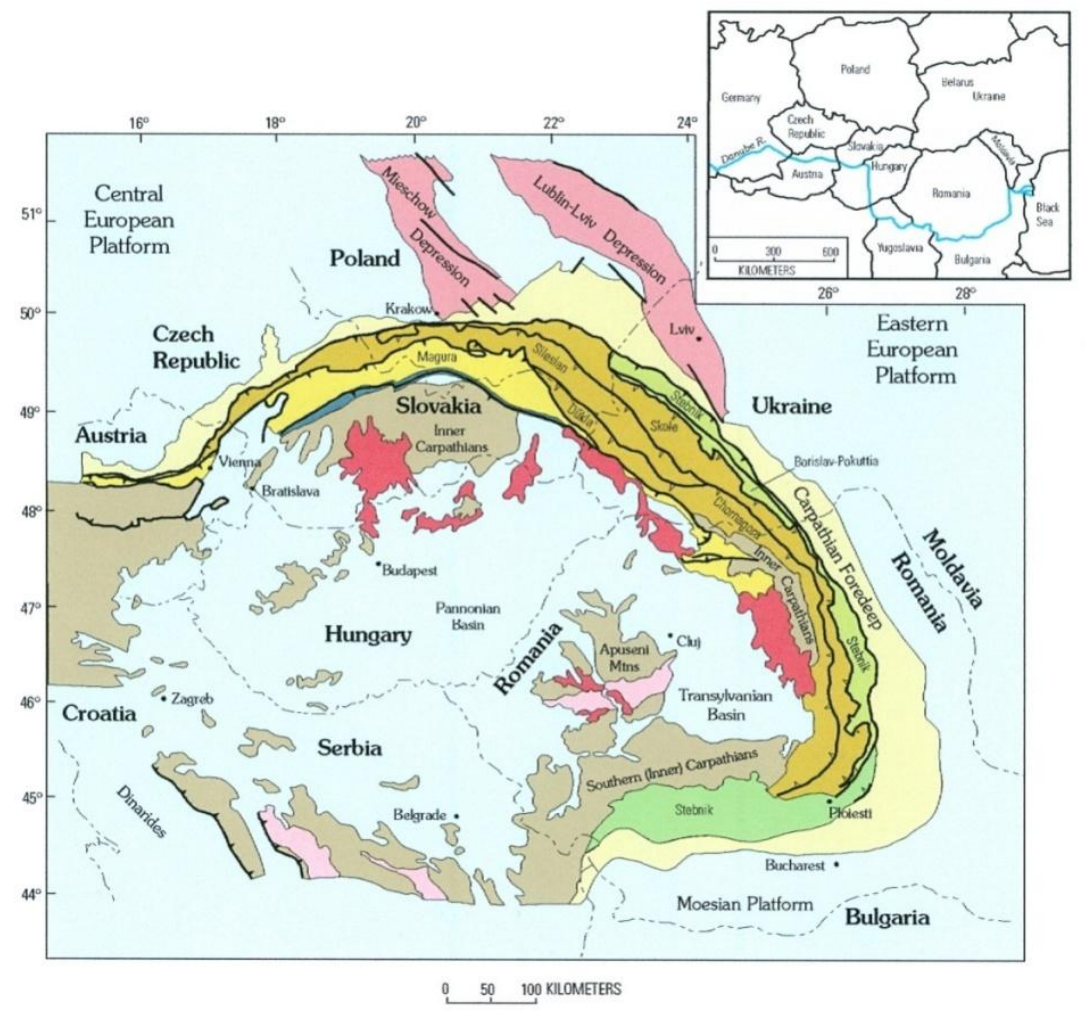

Fig4. The arc of Carpathians. A complicated tectonic structure well seen. Main tectonic units shown in olivegreen colours. The Carpathian Foredeep - leight yellow. The Pieniny Klippen Belt - blue. After Roca et al. (1995), modified.


Fig5. Interpretation of results of fluid inclusion in quartz (the Marmarosh diamonds) and bitumen studies - two directions of maturity increase toward SE and W. Samples description: We 2.2 - Wetlina, BieszczadyMts, Poland; MD1ABi-MszanaDolna,Poland; S1Bi-Stavne, Ukraine.After Jarmołowicz-Szulc et al. (2012). 
Considerations play the so called Marmarosh diamonds, which represent a type of the bi-pyramidal quartz in euhedral, transparent crystals of an ideal crystal habit and a perfect reflection (Dudok, Jarmołowicz-Szulc, 2000). This quartz contains inclusions either of primary or of secondary origin.

Hydrocarbons are very common and widespread in sedimentary rocks in the different Carpathian units and point to mobility and circulation of fluids. The analysis that was conducted has pointed to a presumed HC migration in two directions (Jarmołowicz-Szulc et al., 2012; Fig. 5). The results are important in search for hydrocarbons.

In total, hydrocarbons may come from deep sources and may be expelled following the pattern similar to the Appalachian case discussed above. However, due to the complexity of the Carpathian tectonic structure (Fig. 4, Fig. 6), and following field observations, more detailed studies are necessary, both from the tectonic structure and mineralogical-geochemical points of view.

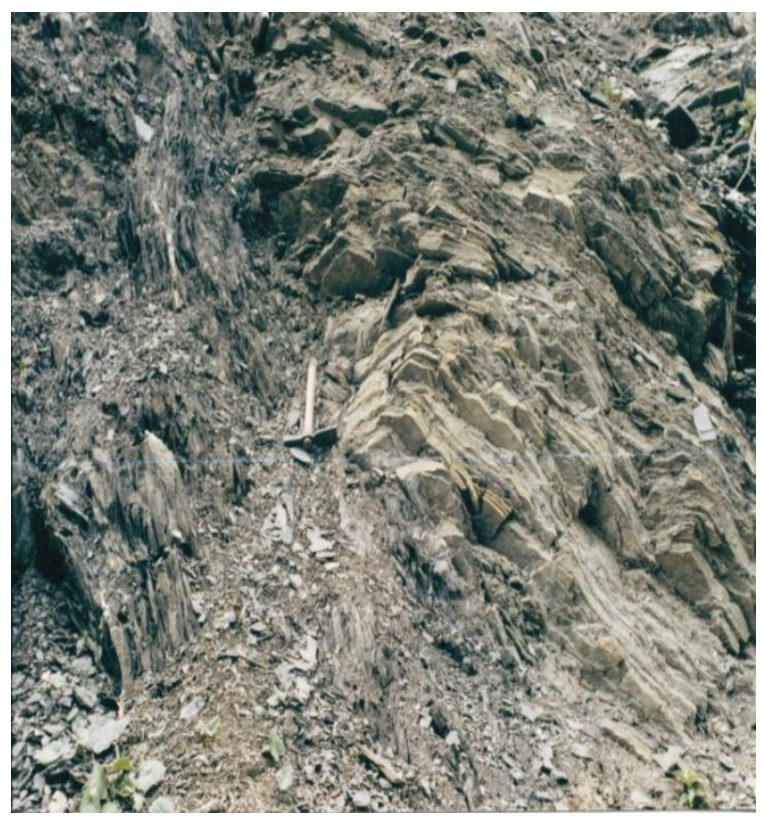

Fig6. Strongly tectonically engaged region in the Carpathians rich in the Marmarosh diamonds. Evident migration paths for fluids (Ukraine). Phot. K. Jarmołowicz-Szulc.

\section{Conclusions}

There exists a strong correlation between tectonic engagement of different geological areas and the occurrence, character and migration of fluids present in the rocks either at macroscopic or microscopic scale. Fluids responsible for a formation of different deposits, in that of oil and gas fields, may have a very deep origin being tectonically expelled from the certain depths. In the Carpathians, further mineralogical, petrological and tectonic studies are necessary for the detailed explanation of fluid origin in the context of the formation of deposits and the genesis of mineral waters, while the exact reconstruction of migration paths will lead e.g., to explanation of oil occurrences still present despite the long-term exploitation.

This paper follows the lecture presented on the $2^{\text {nd }}$ Oil and Gas Conference and Expo in Rome (Italy) in October 2016.

\section{ACKNOWLEDGEMENTS}

Cordial thanks are addressed to IhorDudok for his contribution to the author's studies on the Marmarosh diamonds in Ukraine. Leszek Jankowski is thanked for his long co-operation in field works and sampling in the Polish part of the Carpathians, with a hope for common studies in the area outside Poland in the close future.

\section{BIBLIOGRAPHY}

[1] Cook F.A., Albaugh D.S., Brown L.D., Kaufman S., Oliver J., Petersea T., 1983 - COCORP seismic reflection profiling of the southern Appalachians. AAPG Studies in Geology 14,60 p.

[2] Dudok I.V., Jarmołowicz-SzulcK. 2000 - Hydrocarbon inclusions in vein quartz (the "Marmarosh diamonds" from the Krosno and Dukla zones of the Ukrainian Carpathians. Geol. Quart. 44 (4): 415-423. 
[3] Hopper E., Fischer K.M., Wagner L.S., Hawman R.B., 2016 - Reconstructing the end of the Appalachian orogeny. Geology. DOI: 10.1130/G38453.1.

[4] Jankowski L., Jarmołowicz-Szulc K., 2009 - Particular tectonic zones (the mélange zones) as potential and significant paths for fluid migration and mineral formation. Mineralogical Revue59 (1): $31-44$.

[5] Jarmołowicz-Szulc K., 2009 - Recent contribution to mineralogical and geochemical studies in the Carpathians. Mineralogical Review 59(2): 42-55.

[6] Jarmołowicz-Szulc K., Dudok I.V. 2005 - Migration of palaeofluids in the contact zone between the Dukla and Silesian units, Western Carpathians - evidence from fluid inclusions and stable isotopes in quartz and calcite. Geological Quarterly 49: 291-304.

[7] Jarmołowicz-SzulcK., Dudok I. V., 2000 - Fluid inclusion studies in vein minerals of the Carpathians, Poland - Ukraine. Abstracts of XIth Congress of Regional Commitee in Mediterranean Neogene Stratigraphy, Fes, Morocco, 132.

[8] Jarmołowicz-SzulcK. Karwowski Ł., Marynowski L.,2012 - Fluid circulation and formation of minerals and bitumens in the sedimentary rocks of the Outer Carpathians - based on studies on the quartz-calcite-organic matter association. Marine and Petroleum Geology 32 (1):138-158.

[9] Jarmołowicz-SzulcK.,2016 - Hydrocarbon inclusions in the cements of sedimentary rocks and in vein minerals - characteristic and significance. Biuletyn Państwowego Instytutu Geologicznego 466. DOI:

[10] Leach D. L., Viets J.G., Rowan L., 1984 - Appalachian - Quachita orogeny and Mississippi Valey-type lead-zinc deposits. Geol. Soc. Am. Abstractswithn Programs 12: 572.

[11] Mosier S.O., Waples D.W., 1985 - Quantitative evaluation of Lower Cretaceous Mannville group as source rock for Alberta's oil sands. AAPG Bull. 69:161-172.

[12] Oliver J., 1986 - Fluids expelled tectonically from orogenic belts: Their role in hydrocarbon migration and other geologic phenomena. Geology 14: 99-102.

[13] Pawlewicz M., 2006 - Total petroleum systems of the North Carpathian Province of Poland, Ukraine, Czech and Austria. USGS Bull. 2204-D. Reston, Virginia.

[14] Roca E., Besserau G., Jawor E., Kotarba M., Roure F., 1995- Pre-Neogene evolution of the Western Carpathians: Constraints from the Bochnia - Tatra Mountains section (Polish Western Carpathians). Tectonics 14: 855-873.

[15] RoedderE., 1984-Fluid inclusions. Reviews in Mineralogy 12, 644 p. 